\title{
PRIMAVERAS, TRANSPLANTES, RIZOMA (SOBRE A NATUREZA TÉCNICA DA CULTURA) ${ }^{1}$
}

\section{SPRINGTIMES, TRANSPLANTS, RHIZOME (ON THE TECHNICAL NATURE OF CULTURE)}

Resumo: Este artigo explora algumas leituras a respeito da natureza no "Novo Mundo" buscando articulá-las com o motivo do "transplante", amplamente utilizado por intérpretes modernistas da nossa cultura, e seu pressuposto arborescente. Em contraste com essas leituras, salientamos a força crítica de propostas rizomáticas para o entendimento da história e da cultura, destacando para isso os trabalhos de artistas e escritores.

Palavras-chave: Transplante; Rizoma; Técnica; Cultura.

Abstract: This article explores some readings about nature in the "New World", seeking to articulate them with the "transplant" motif, widely used by modernist interpreters of our culture, and its arborescent assumption. In contrast to these readings, we highlight the critical strength of rhizomatic proposals for understanding history and culture, focusing the work of artists and writers.

Keywords: Transplant; Rhizome; Technique; Culture.

\section{Uma primavera perene}

Desde o denominado descobrimento, a natureza foi um motivo privilegiado para a definição da singularidade da situaçáo latino-americana. Os primeiros ibéricos parecem ter encontrado nos trópicos uma natureza desconhecida, muitas vezes abordada a partir de um complexo sistema de

${ }^{1} \mathrm{O}$ argumento deste texto foi sumariamente apresentado no II Seminário do Núcleo Oco de Arte(s): “Ocas Primaveras", em setembro de 2019, na Universidade Federal de Santa Catarina (UFSC). Agradeço a Carlos Eduardo Capela a escuta no evento e, depois, a atenta leitura desta versão do trabalho. 
representaçóes em que o maravilhoso era um traço central ${ }^{2}$. Sérgio Buarque de Holanda (2010, p. 13) apontou a fecundidade da imagem do Éden durante a ocupação do Novo Mundo, continuamente presente "na imaginaçáo de navegadores, exploradores e povoadores do hemisfério ocidental.". Como afirma no prefácio à segunda edição de Visão do paraíso, publicada em 1969, civilizados recém-saídos da Idade Média encontravam nos trópicos uma primavera sem fim:

\begin{abstract}
Não admira se, em contraste com o antigo cenário familiar de paisagens decrépitas e homens afanosos, sempre a debater-se contra uma áspera pobreza, a primavera incessante das terras recém-descobertas devesse surgir aos seus primeiros visitantes como uma cópia do Éden. Enquanto no Velho Mundo a natureza avaramente regateava suas dádivas, repartindo-as por estações e só beneficiando os providentes, os diligentes, os pacientes, no paraíso americano ela se entregava de imediato em sua plenitude, sem a dura necessidade - sinal de imperfeição - de ter de apelar para o trabalho dos homens. (HOLANDA, 2010, p. 13).
\end{abstract}

O autor de Raízes do Brasil discorre sobre a pregnância desse motivo edênico nas muitas descrições medievais, oriundas, em geral, da elaboração de Lactâncio - "ou de quem fosse o autor do poema latino Phoenix" (HOLANDA, 2010, p. 24) -, no final do sec. III ou início do sec. IV, que já cunhara o topos de uma perene primavera relacionada à temperança do ar: um ar nem frio nem quente. Na costa do Brasil, Pero Vaz de Caminha e, sobretudo, Pero de Magalhães Gândavo cumpriram seus papeis de relatores e propagandistas do descobrimento, salientando a prodigalidade animal e vegetal das novas terras, além de seus bons ares, é claro que sem desconsiderar as ambicionadas promessas minerais. $\mathrm{O}$ tema da abundância e do viço da natureza, da constante primavera do Novo Mundo, foi, portanto, um "lugar-comum" cultural, que pode ser encontrado também nos cronistas Colombo e Vespúcio, assim como nos padres Anchieta, Nóbrega e Cardim, entre outros. Afinal, tudo, aqui, daria e duraria, em razáo de uma disposição natural; mas apenas na medida em que natural, então, equivalia a providencial. Mesmo os povos indígenas, em sua ambígua animalidade - suspensos, como

\footnotetext{
2"O maravilhoso é, pois, um traço central no complexo sistema de representação como um todo, seja ele verbal ou visual, filosófico ou estético, intelectual ou emocional, através do qual as pessoas da Idade Média tardia e da Renascença apreendiam, e portanto possuíam ou descartavam, o não-familiar, o estranho, o terrível, o desejável e o odioso" (GREENBLATT, 1996, p. 40). E ainda: "na América o maravilhoso e a imagem das riquezas coincidiam. O fundo do maravilhoso americano foi, quase exclusivamente, econômico. [...] O maravilhoso se apoia no desconhecimento ou na falta de hábito" (GIUCCI, 1992, p. 13-14).
} 
limiares, entre a pureza e a bestialidade -, eram parte das generosas dádivas da natureza, muitos cronistas divulgando a suposta longevidade extrema dos índios do novo continente. Respondendo ao pragmatismo necessário à colonização, no entanto, caberia ao civilizador domesticar certas resistências da índole dos selvagens, como a prática do canibalismo e a inconstância das almas, não repercutindo nos trópicos consideraçóes extemporâneas como as de Michel de Montaigne ou de Bartolomeu de Las Casas, ambos, como sabemos, severos na crítica ao barbarismo dos europeus, ou mesmo os relatos de Jean de Léry (matriz calvinista) ou de Hans Staden (matriz luterana), que relativizavam o juízo sobre os costumes dos povos originários (MONTAIGNE, 1996; LÉRY, 1980; STADEN, 1974). Em suma, ao que parece, no imaginário das grandes navegaçóes tiveram menor força os ventos contrários aos clichês sedutores, primaveris e edênicos³ .

Ou seja, os bons ares do Novo Mundo pareciam barrar a ideia de que, por aqui, também um inferno podia ser encontrado, ou melhor, produzido. O que não impediu de ser registrado, em primeira mão, na pena de Ulrico Schmidel. Mercenário bávaro sob o comando de Pedro de Mendoza, Schmidel navegara de Cádiz, em 1534, rumo ao Río de la Plata, onde participou da primeira tentativa de fundação de Buenos Aires, aí testemunhando a derrota da mesma empresa. A incipiente fortificação foi devastada, os barcos foram incendiados, e seus homens sucumbiram em razão da fome, da sede, das duras imposiçôes do ambiente e do assédio dos indígenas querandís (SCHMIDL, 1993). Isso não sem antes de, em desespero, comerem cavalos, botas e outros couros, ratos, ratazanas e víboras, além dos próprios companheiros cristãos já mortos ${ }^{4}$. Se o emblemático episódio, que pode ser

\footnotetext{
${ }^{3}$ Afirma Buarque de Holanda (2010, p. 32): "Quanto às imagens negativas que pôde suscitar o Novo Mundo, nada mostra que fossem aos mesmos extremos a que chegou a sua idealização. Ou melhor, não conseguiram cristalizar-se, salvo como opinióes individuais e sem muita força de contágio, em qualquer coisa que merecesse chamar-se um antiparaíso ou, se quiserem, uma visăo do inferno, capaz de contrapor-se às inumeráveis visôes edênicas que inspiraram as novas terras".

4" $Y$ ahi se levantó un asiento y una casa fuerte para nuestro capitán general don Pedro Mendoza y un muro de tierra en derredor del asiento de una altura hasta donde uno podía alcanzar con una tizona. (También) este muro era de tres pies de ancho y lo que se levantaba hoy se venía mañana de nuevo al suelo; pues la gente no tenía qué comer y se moría de hambre y padecía gran escasez. (También) se llegó al extremo de que los caballos no daban servicio. Fue tal la pena y el desastre del hambre que no bastaron ni ratas ni ratones, viboras ni otras sabandijas; también los zapatos y cueros, I todo tuvo que ser comido. / Sucedió que tres españoles habian hurtado un caballo y se lo comieron a escondidas; y esto se supo; asi se los prendió y se les dio tormento para que confesaran tal hecho; asi fue pronunciada la sentencia que a los tres susodichos españoles se los condenara y justiciara y se los colgara en una horca. Asi se cumplió esto [...]. Ni bien se los habia ajusticiado y cada hombre se
} 
considerado um dos eventos inaugurais da globalização na região, coincide com o estabelecimento do domínio espanhol, que daí então margeou o Rio da Prata de modo permanente, ele coincide, igualmente, com o avanço da destruição; e sem dúvida não é de estranhar que, desde a crônica de Schmidel, que contou com ilustraçóes das casas editoras de Theodore de Bry e de Levinus Hulsius, ele retorne em muitas leituras contemporâneas que revisam criticamente o arquivo do descobrimento, diríamos que a fim de desnaturalizá-lo, entre elas as de artistas como Oscar Esteban Conti (Oski), León Ferrari, Fernando Birri e Luis Felipe Noé (GIORGI, 2016; LINK, 2012; REP; VACCARI, 2013; OSKI, 2006).

\section{Descobrimentos}

Ora, isso obviamente quer dizer que náo se tratou, de fato, de um descobrimento. Mas o privilégio desse significante tendeu a naturalizar um sentido dadivoso, ditoso, algo como uma fortuna providencial que irradiaria do suposto achado; algo que, ofuscante - e por isso obliterando olhares, matizes -, selaria uma promessa de imenso presente. Insistindo no óbvio: não houve tal "descobrimento". Houve, talvez, chegada; de alguma forma, houve mesmo fundação, começo, invenção, achamento, construção, contato, contágio; sem dúvida, houve conquista; e certamente, ainda, aculturação, invasâo, destruição. Seja como for, está posto, mas na falta de reparação, é importante que digamos de novo: o desastre, ou seja, o aparente sucesso da empresa colonizadora e exploratória dependeu de sua eficácia genocida, da insistente mobilização de forças de domesticação, controle e extermínio dos povos autóctones. Isso por um lado. $\mathrm{E}$, todavia, por outro lado, a naturalizaçáo do descobrimento é impugnada pelas cartografias, pelos planisférios, globos e relatos que já sinalizavam, coevamente às grandes navegaçóes, a existência do que seria chamado de continente americano; e ainda, pela exposição da singular maneira de compreender e conter a diferença, exercitada pelos descobridores: de neutralizá-la relacionando-a com uma identidade insituável, a partir do íntimo compromisso entre o conhecido e o desconhecido, a topologia e a topografia, a literatura e a crônica, o imaginário e a realidade, com o qual o paraíso sempre se

fue a su casa y se hizo noche, aconteció en la misma noche por parte de otros españoles que ellos han cortado los muslos y unos pedazos de carne del cuerpo y los han llevado a su alojamiento / y comido. (También) ha ocurrido en esa ocasión que un español se ha comido su propio hermano que estaba muerto. Esto ha sucedido en el año de 1535 en nuestro día de Corpus Christi en el sobredicho asiento de Buenos Aires." (SCHMIDL, 1993, p. 12-13). 
deslocaria, situando-se ou no passado, ou no futuro, ou no sonho, em todo caso alheio e adverso ao presente (FINAZZI-AGRÒ, 2013; HOLANDA, 2010). Paradoxos que não passaram despercebidos por artistas e escritores contemporâneos às voltas com o legado da colonização.

É nesse sentido que se desenvolve Los indios estaban cabreros, "farsátira en tres actos" (CUZZANI, 1958, p. 1), de acento niilista, do dramaturgo pop Agustín Cuzzani. Na peça, publicada em Buenos Aires em 1958 e amparada em antigos relatos e mitos de distintos povos, o pioneirismo dos descobrimentos se dá ao revés, num tempo que corresponderia ao ano 1491, cabendo a índios mexicanos a viagem às terras do Deus-Sol no Oriente, a fim de lhe denunciarem violências e desmandos cometidos por seus próprios sacerdotes 5 . Cuzzani não mobiliza nostalgias de algo para sempre perdido: em busca do paraíso e da salvação, os indígenas da sua peça nada mais encontram, em solo europeu, além de outros semblantes que traduzem seus próprios medos, mitos e projeçóes ${ }^{6}$. Agora, ainda mais

${ }^{5}$ Cuzzani foi advogado, escritor, professor de dramaturgia e roteirista de cinema, rádio e televisão. No primeiro ato, a peça se desenvolve numa pequena aldeia às margens do Attântico, "en los costados mejicanos del Imperio de Tuasantisuyu, provincia vasalla de Michocoan, en tiempos en que Axayaca era Uei Toatlon, es decir, emperador, en el año 12 de las cañas de la octava gavilla - era mejicana correspondiente al año 1491 de nuestra era". Retornado do exílio, um príncipe - Tupa - é descoberto; então anuncia: “- Óiganme todos. No habrá otra revolución como las anteriores. Mientras los sacerdotes tengan engañado al Dios-Sol toda batalla será inútil. (A Chola). ¿Recuerdas mis preguntas de las otras noches? ¿Sabe el Sol lo que ocurre con sus hijos? ¿Oye nuestros lamentos y nuestras plegarias? Yo... iré a buscar las respuestas. Navegaré. Navegaré con esta balsa hacia el este, donde sale el sol todas las mañanas. Navegaré hasta el fin del mar y golpearé a las puertas de Sol bien de mañana. Y pediré por ti, y por él, y por todos nosotros. Le diré la verdad. No tengo más que esa balsa y el viento. Esa es toda mi nueva revolución. (A Chola). ¿Sigues creyendo que huyo, muchacha?" (CUZZANI, 1958, p. 21).

${ }^{6}$ Veja-se a conversa entre dois índios, Tupa e Tonatio, e Colombo: "COLÓN - Yo quería navegar hacia Occidente para llegar al horizonte y entrar en los cielos, llegarme a la Casa de Dios y contarle de mi propia boca los infinitos males y miserias que sufren las gentes de este mundo... TUPA - ¿Cómo... buscabas a Dios por el Poniente? COLÓN - (Se vuelve extrañado) Claro... Todo viaja hacia Occidente. Las estrellas, el sol, la luna... las más viejas leyendas. Todo indica el camino. TUPA - Yo llegué a esta tierra buscando a Dios por el Oriente. COLÓN-Y ya ves lo que encontraste. En cambio, por el Oeste... TONATIO - Ya verás lo que encontrarás... ”. Já no epílogo, Cuzzani argumenta: "Hacia el cardinal de lo posible: Un viaje de indios americanos a España al tiempo que los españoles planeaban su viaje a América, resulta lo más armónico, lógico y natural, si arrancamos de muy antiguas leyendas y mitologias hebreas, egipcias, babilónicas, griegas, así como aztecas, mayas, toltecas o de todo el nahuac./ Todo Oriente empuja al hombre a buscar más allá del mar, tierras a Occidente./ Todo occidente americano, empuja a buscar tierras al Oriente. Y en ese orden de premisas, mi principe Tupa viajando hacia España, empujado por viejísimas tradiciones mejicanas, es tan posible como ese extraño y casi legendario Cristóbal Colón buscando el paraíso terrenal al Occidente de Europa." (CUZZANI, 1958, p. 52-57). 
notável é como se dispóe a leitura de Luis Felipe Noé sobre a cartografia acessível aos navegantes na época dos descobrimentos, à luz de testemunhos deixados principalmente por Colombo. Por meio de um procedimento de montagem, num livro chamado A Oriente por Occidente. Descubrimiento del llamado descubrimiento o (del origen) de lo que somos y no somos (figura 1), editado em Bogotá (1992), Noé expóe como é relativa a centralidade dos discursos da história oficial, ou ainda, que a centralidade é um efeito do exercício de poder:

O conhecimento que se tinha da atual América, que figura aderida a Ásia no planisfério de Martellue e no globo terráqueo de Behaim - o qual demonstra que em 1492 tinha-se plena consciência da redondeza da terra - era um conhecimento adquirido desde o Pacífico e não por europeus. (NOÉ, 1992, $\mathrm{s} / \mathrm{p}){ }^{7}$

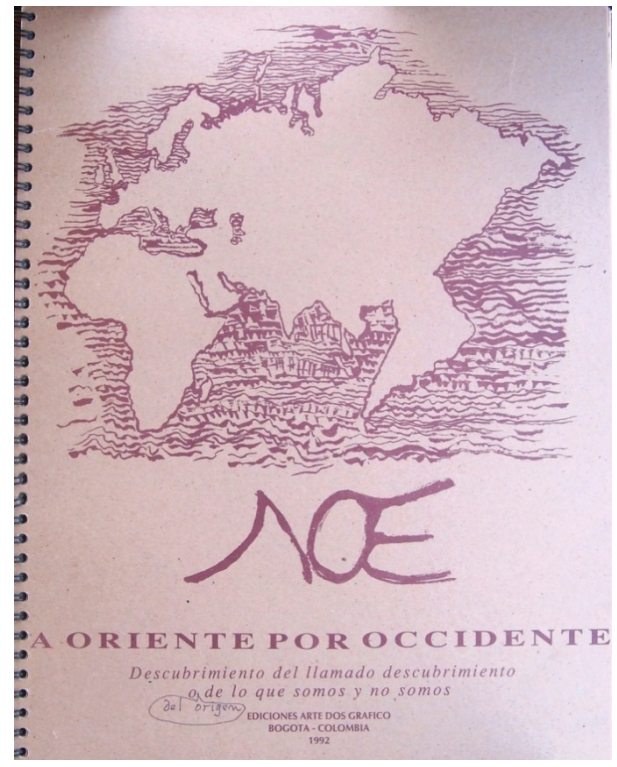

Figura 1: Luis Felipe Noé, A Oriente por Occidente. Descubrimiento del llamado descubrimiento o (del origen) de lo que somos y no somos, 1992 (folha de rosto).

\footnotetext{
7 "El conocimiento que se tenía de la Actual América, que figura adherida a Asia en el planisferio de Martellue y en el globo terráqueo de Behaim - el cual demuestra que en 1492 se tenía plena conciencia de la redondez de la tierra- era un conocimiento adquirido desde el Pacifico y no por europeos." (NOÉ, 1992, s/p).
} 
Em outras palavras, Noé aponta que Colombo "descobriu" terras que a rigor já figuravam em mapas anteriores à sua primeira viagem; e levando-se em conta os termos do acordo firmado previamente por Colombo e os reis católicos da Espanha nas Capitulaçóes de Santa Fé, poderíamos dizer que, caso tenha havido algum descobrimento, este foi "de direito", não "de fato", embora a conquista - que o autor nomeia holocausto - tenha sido por meio do poder de fato, não de direito. Qual seria, então, a estratégia? Noé propóe a seguinte: a história ocidental é movida por paradoxos, e esta é a "chave de nossos maiores defeitos societários mas também de nossa maior riqueza cultural"; contudo, "como sem poder não há descobrimento, essa riqueza não será reconhecida até que tenhamos a coragem de assumir o poder de descobrir a nós mesmos e fazer os outros crerem que sáo eles que nos descobrem" (NOÉ, 1992, s/p) ${ }^{8}$. A origem da ontologia na cultura ocidental deve ser buscada, para Noé, numa paradoxal definição comunitária, não excludente ou opositiva, tampouco sintética ou apaziguadora, uma vez que comporta a própria dessemelhança: como diz o título do livro, a questão recai sobre o que "somos e não somos". E por isso não se trata do descobrimento de qualquer natureza, nem a "mesma", nem "outra”; trata-se, sim, do descobrimento do chamado descobrimento, isto é, do enfrentamento de ficções, da prótese do descobrimento: "a origem" vem grafada na capa e na folha de rosto de modo a emular um enxerto, um suplemento caligráfico, adicionado à impressão a posteriori. Para o homem, ser de linguagem, qualquer natureza - parecem apontar tais experiências - é de segunda ordem: é técnica.

Não poucos reforçaram a leitura dessa natureza protética. Lembremos, nesse sentido, apenas duas situaçóes, duas vozes da crítica que recolocaram a questão de maneira muito significativa. A primeira se encontra na leitura que Raúl Antelo faz da experiência de Henri Michaux nos trópicos:

Quase no fim do percurso de Equador (1929), navegando o Amazonas como turista aprendiz, Henri Michaux pergunta-se "mais où est l'Amazon?", o que o conduz a uma pergunta ontológica mais capital ainda, "Mais, où est-il ce voyage". Embora Michaux esteja no rio, navegue por ele, ele não vê o rio. Para vê-lo é preciso subir, vê-lo do alto, não basta a horizontalidade do deslocamento, mas exige-se, fundamentalmente, a verticalidade da abstração, uma cartografia, uma ficção. "Il faut l'avion", a técnica, os dispositivos da Europa, a linguagem, o poder. "Je n'ai donc pas vu l'Amazone” (ANTELO, 2012, p. 12).

\footnotetext{
8"clave de nuestros mayores defectos societarios pero también de nuestra mayor riqueza cultural [...] como sin poder no hay descubrimiento, esa riqueza no será reconocida hasta que tengamos el coraje de asumir el poder de autodescubrirnos y hacer creer a los otros que son ellos los que nos descubren" (NOÉ, 1992, s/p).
} 
Para Raúl Antelo (2012, p. 12), Michaux estava consciente de "só ver o Amazonas através da escrita”. Assim como, para Carlos Eduardo Capela - e esta é a segunda lembrança -, o narrador Euclides da Cunha demanda o agenciamento da escrita para poder ver esse escoamento que vem a ser o rio: é somente com os olhos ardidos de uma noite insone, consumida na leitura de uma monografia de Jacques Huber sobre a região amazônica, que o viajante Euclides da Cunha, ao nascer do dia, desperta e "anuncia, admirado, a epifania que ocorrera, a descoberta da Amazônia" (CAPELA, 2011, p. 13) $)^{9}$.

O deslumbre de Euclides da Cunha passa pela palavra; é despertado por ela, que assim pode seguir em seu jorro excessivo. A cena revela como, para a personagem do escritor, a natureza se apresenta menos em si mesma, ou por si mesma, do que através da intervençấo, lancinante, de um texto que, embora arda os olhos, conforma o olhar. Um texto que remete a outros textos, que a um só tempo o prefiguram e o reconfiguram, projetando-se a partir daí uma espécie de comovência ou abertura na qual se descortina uma escritura em processo, que se escreve e ao se escrever inscreve e excreve o visto, o sentido, que delineia ou esboça o inesgotável que vê a própria visão. A paisagem, com isso, retira-se de si, suspende-se e se estende para se dar enquanto passagem, lugar de encontro - palavra. (CAPELA, 2011, p. $14-15) \cdot{ }^{10}$

\section{Transplantes}

E, contudo, moduladas de distintas maneiras, as imagens orgânicas, de efeito naturalizante, não deixaram de apoiar uma vertente hegemônica da crítica moderna a respeito dessa natureza técnica da cultura. Talvez o motivo do "transplante" (e suas variantes, como a "transplantaçáa", o "implante", a "implantação" etc.), em geral deslocado como metáfora do

\footnotetext{
${ }^{9} \mathrm{O}$ texto em questão é aquele lido na sessão em que Euclides da Cunha toma posse na Academia Brasileira de Letras, citado a partir do volume I da Obra Completa; mas que pode ser conferido no sitio web da Academia: http://www.academia.org.br/academicos/euclides-dacunha/discurso-de-posse. Acesso em: 25 set. 2019.

${ }^{10} \mathrm{O}$ conceito de excrito ou excritura faz referência a Jean-Luc Nancy, que por sua vez lê Bataille: "[...] Bataille me comunica inmediatamente la pena y el placer que provienen de la imposibilidad de comunicar cualquier cosa sin tocar el limite en el que el sentido todo entero se derrama fuera de si mismo, como una simple mancha de tinta a través de una palabra, a través de la palabra 'sentido'. A ese derramamiento del sentido que produce el sentido, o a ese derramamiento del sentido a la obscuridad de su fuente de escritura, yo lo llamo lo excrito." (NANCY, 2002, p. 39, grifos do autor).
} 
vocabulário botânico, seja um dos mais produtivos para acompanharmos esse problema. Com efeito, indissociável do próprio problema da definição do nacional, vale dizer, dos impasses da fundaçáo e da autonomia abordados emblematicamente desde o romantismo, passando por autores como José Veríssimo e Silvio Romero, o "transplante" é uma das marcas de um princípio operatório que, no século $\mathrm{XX}$, atravessa uma série de estudos de matriz sociológica e antropológica, em torno dos desafios da modernização e dos debates sobre a identidade brasileira, o progresso científico, a dependência cultural, o desenvolvimento econômico, a soberania política etc. Ou seja, seu campo de ação é mesmo demasiado vasto; coincide, de fato, com a emergência da máquina biopolítica moderna ${ }^{11}$, de modo que mereceria um estudo mais detido, a fim de apreendermos melhor as suas nuances - seria necessária uma verdadeira "arqueologia do transplante".

De qualquer modo, parece haver uma constância, um pressuposto que serve a esses estudos como uma espécie de princípio operatório, como já sugerido, ou ainda como o que poderíamos chamar protocolo de leitura. Vale enunciá-lo desde já: grosso modo, para os intérpretes em questáo, a cultura pode ser compreendida nos termos de um vitalismo arborescente, das raízes à floração, o que lhe confere um padrão organicista evolutivo, ascendente, linear, estando assim bem enraizada no solo de uma história

\footnotetext{
${ }^{11}$ Para Foucault, a emergência da biopolítica se dá com o deslocamento do "Estado territorial" para o "Estado de população", no marco dos governos liberais. Ou seja: "o liberalismo como quadro geral da biopolítica" (2008, p. 30). Lemos na primeira aula do curso dedicado ao Nascimento da biopolítica, em janeiro de 1979: "Eu tinha pensado lhes dar este ano um curso sobre a biopolítica. Procurarei lhes mostrar como todos os problemas que procuro identificar atualmente, como todos esses problemas têm como núcleo central, claro, esse algo que se chama populaçấo. Por conseguinte, é a partir daí que algo como a biopolítica poderá se formar. Parece-me, contudo, que a análise da biopolítica só poderá ser feita quando se compreender o regime geral dessa razão governamental de que lhes falo, esse regime geral que podemos chamar de questáo de verdade - antes de mais nada da verdade econômica no interior da razáo governamental -, e, por conseguinte, se se compreender bem o que está em causa nesse regime que é o liberalismo, o qual se opõe à razão de Estado, ou antes, [a] modifica fundamentalmente sem talvez questionar seus fundamentos. Só depois que soubermos o que era esse regime governamental chamado liberalismo é que poderemos, parece-me, apreender o que é a biopolítica." (FOUCAULT, 2008, p. 29-30, grifos do autor). Já Giorgio Agamben faz da biopolítica o paradigma do ordenamento ocidental: "a implicação da vida nua na esfera política constitui o núcleo originário - ainda que encoberto - do poder soberano. Pode-se dizer, aliás, que a produção de um corpo biopolítico seja a contribuição original do poder soberano. A biopolítica é, nesse sentido, pelo menos tão antiga quanto a exceção soberana. Colocando a vida biológica no centro de seus cálculos, o Estado moderno não faz mais, portanto, do que reconduzir à luz o vínculo secreto que une o poder à vida nua, reatando assim (segundo uma tenaz correspondência entre moderno e arcaico que nos é dado verificar nos âmbitos mais diversos) com o mais imemorial dos arcana imperii." (2007, p. 14, grifos do autor).
} 
também ela já assimilada pela incontornável lógica "natural", positiva, do progresso $^{12}$. Além disso, na base desse protocolo interpretativo, é igualmente significativa a legitimidade atribuída à gênese, aos antecedentes responsáveis pela geração, portanto, à filiaçáo da cultura em questáo; aos troncos, galhos e ramos descendentes caberia, a partir dessa reconhecida herança, passada nos moldes de uma propriedade genética, decidir pela continuidade, pela ruptura, pela depuraçáo, ou por qualquer outro recurso que lhes permitisse, afinal, nutrir propriamente o seu desenvolvimento.

Como já dito, problema antigo, que todavia não cessa de retornar, principalmente quando a natureza técnica da cultura é constrangida por razóes imunitárias, estas sempre amparadas por um léxico que remete à naturalizaçáo dos seus efeitos e limites. Se a arqueologia desse pensamento escapa aos limites desta exposição, gostaríamos, não obstante, no que segue, de apontar brevemente algumas recorrências e variantes do motivo do "transplante", para depois confrontá-las com alternativas - não contrárias, por certo, a esse motivo específico ou ao uso metafórico da linguagem (o que seria um absurdo), mas sim ao pressuposto organicista e arborescente que certas leituras tendem a cristalizar, e em cuja base parece estar a manutenção de uma lógica tributária da gênese, da presença ativa do fundamento e da identidade, em suma, da ontologia idealizada e imposta, teleologicamente, como um todo positivo, evolutivo, natural.

Num mapeamento muito sumário, encontramos o topos do "transplante", na trilha da tradição modernista, no já citado Raízes do Brasil, de Sérgio Buarque de Holanda. "A tentativa de implantaçáo da cultura europeia em extenso território, dotado de condiçóes naturais, se não adversas, largamente estranhas a sua tradição milenar, é, nas origens da sociedade brasileira, o fato dominante e mais rico em consequências", nos diz o autor no primeiro parágrafo do livro, publicado em 1936, que assim continua: "Trazendo de países distantes nossas formas de convívio, nossas instituiçóes, nossas ideias, e timbrando em manter tudo isso em ambiente muitas vezes desfavorável e hostil, somos ainda hoje uns desterrados em nossa terra" (HOLANDA, 1995, p. 31). Três anos antes, Gilberto Freyre já se valera do motivo em Casa-grande \& Senzala, no contexto de

12"Para que o adjetivo moderno tenha tomado o sentido nebuloso que tem para nós, a invenção do progresso foi indispensável, isto é, a definição de um sentido positivo do tempo, como observa Octávio Paz. [...] Uma concepçáo positiva do tempo, isto é, a de um desenvolvimento linear, cumulativo e causal, supóe certamente o tempo cristáo, irreversível e acabado. Mas ela o abre para um futuro infinito. Essa concepção se estendeu à história, em particular à história da arte, como uma lei de aperfeiçoamento, descoberta a partir do século XVI, nas ciências e nas técnicas." (COMPAGNON, 1996, p. 19). 
comparação das dificuldades encontradas por negros e por europeus no processo de "transplantação" de hábitos alimentares para o Brasil, com vantagem, no caso, para os negros (FREYRE, 2003, p. 373). Em 1955, Afrânio Coutinho, por sua vez, procederia a um levantamento de algumas características "na evolução de nossa literatura e de nossa atividade literária" (COUTINHO, 1986, p. 35). Entre elas, enumera a "exaltação da natureza", a "ausência de tradição" e a "ausência de consciência técnica", condiçôes de uma "literatura de transplante" em que, afirma o autor, "o dilema da imitação e da originalidade polariza a consciência dos escritores". Claro, trata-se de uma "impressão pessimista". Afrânio Coutinho (1986, p. 39) ajuíza: "É uma literatura pobre. Ainda não chegamos mesmo à plena posse de uma literatura".

Mais célebre, no entanto, seria a hipertrofia da noção promovida por Antonio Candido em razão do seu argumento definidor da "literatura como sistema", isto é, da "literatura propriamente dita" (CANDIDO, 2000, p. 23), no canônico Formaçáo da literatura brasileira, preparado entre as décadas de 1940 e 1950 . No prefácio à primeira edição da obra, encontramos a emblemática fórmula, que mal disfarça um mesmo tom de reprovação: "A nossa literatura é galho secundário da portuguesa, por sua vez arbusto de segunda ordem no jardim das Musas... Os que se nutrem delas são reconhecíveis à primeira vista, mesmo quando eruditos e inteligentes", avalia Candido, na medida em que apresentam "gosto provinciano e falta do senso de proporçôes”. Como Afrânio Coutinho, Candido assevera: "Comparada às grandes, a nossa literatura é pobre e fraca. Mas é ela, não outra, que nos exprime. Se não for amada, não revelará a sua mensagem; e se não a amarmos, ninguém o fará por nós" (CANDIDO, 2000, p. 9-10).

Uma lógica afim conduziria, como sabemos, as análises de Roberto Schwarz, em textos como Cultura e política, 1964-1969, As ideias fora do lugar e Nacional por subtração. Neste, o autor contra-argumenta as críticas de Silvio Romero a Machado de Assis e afirma: "A denúncia do transplante cultural veio a ser o eixo de uma perspectiva crítica ingênua e difundida" (SCHWARZ, 1987, p. 48). Schwarz aponta uma série de inconvenientes ocasionados por um entendimento elitista do problema da imitação de modelos; inconvenientes que, para ele, poderiam ser resolvidos pragmaticamente, desde um ponto de vista estético e político, com a inclusão dos maiores interessados, a saber, os excluídos do universo da cultura. Ora, estamos nas vizinhanças de outras proposiçóes bem conhecidas: as apresentadas por Ferreira Gullar em seus ensaios "participantes". Publicado em 1969, pouco antes de Literatura e subdesenvolvimento, de Antonio 
Candido, e argumentando a seu modo que, no Brasil, as ideias estavam fora do lugar (alheias, foram apropriadas num contexto dependente e atrasado, diverso, portanto, daquele - europeu ou estadunidense - que determinava a pertinência do seu uso primeiro), Vanguarda e subdesenvolvimento (GULLAR, 2006) repóe a tese da relatividade da vanguarda artística. Tese, é claro, inserida num amplíssimo debate em torno do nacionalismo e do problema da dependência que, sabemos, mobilizou grande parte da intelectualidade de esquerda, não só no Brasil (no eixo Rio-São Paulo, em núcleos como o ISEB e o CEBRAP, por exemplo, além da Revista Civilização Brasileira, de Ênio Silveira). No prefácio à segunda edição, escrito em novembro de 1997, Gullar (2006, p. 168-169) reforça:

\begin{abstract}
Outro ponto a que gostaria de me referir diz respeito ao caráter diferente que ganham as ideias europeias quando transplantadas para um meio atrasado, que pouco tem a ver com aquele em que surgiram. [...] Trata-se de uma questão de extrema complexidade que envolve a compreensão justa do fenômeno cultural nos países capitalistas europeus na época da formação da sociedade brasileira e a compreensão também do fenômeno no Brasil de então, cuja economia se baseava na mão-de-obra escrava. A defasagem entre os dois meios sociais determinou uma flexáo das ideias e formas transplantadas, razão por que o estudo dessa flexão torna-se imprescindível para o entendimento do processo cultural dependente brasileiro.
\end{abstract}

Desse amplo debate, que mereceria um mapeamento mais cuidadoso, participaram também Darcy Ribeiro, Mário Pedrosa e Alfredo Bosi - e com a referência a seus trabalhos encerraremos este breve levantamento. Em Darcy Ribeiro o uso do motivo é declaradamente tipológico: faz parte de um trabalho abrangente que propóe a caracterização dos povos americanos, em que os "povos transplantados" corresponderiam aos do norte do continente ${ }^{13}$. Assim, diríamos que leva a um entendimento do "transplante" em que seu sentido parece ser mais afinado com a possível manutençáo das características "originárias" do que com um inevitável e polêmico desvio.

Mário Pedrosa (1998), por sua vez, retoma, dotando-o de signo

\footnotetext{
${ }^{13}$ No capítulo de As Américas e a civilizaçáo dedicado à categoria, que se inicia com uma citação de Simón Bolívar, lê-se que os povos transplantados, emblematicamente os do Norte, são constituídos por europeus emigrados que mantêm, no novo continente, a sua cultura matriz (não por assimilação ou integração, mas, sobretudo, por discriminação e segregação); e que tais povos contrastam com as demais configuraçôes socioculturais da América por esse europeísmo manifesto não apenas no tipo racial, predominantemente caucasiano, mas também na paisagem criada como reproduçáo do Velho Mundo e no caráter mais amadurecido de sua economia capitalista (RIBEIRO, 2007).
} 
positivo, o desvio fundacional, antes apontado por Sérgio Buarque de Holanda. O "transplante" que evidencia a ausência de uma tradição nacional própria é precisamente o que "condena" a cultura brasileira ao moderno. Desse modo, reivindicaria não um gesto "descobridor", mas construtor, a valer uma lógica que afirma que uma civilização pode surgir, como um oásis, ali mesmo onde e porque uma cultura natural foi inexistente ou impossível ${ }^{14}$. O avanço seria propiciado pelo contato do dado local, bruto, com a técnica, com um poder que, aos olhos otimistas do crítico, neste caso, parecia ser neutro, em sua capacidade criadora e geradora de síntese, ou seja, de natureza. Em poucas palavras: para Pedrosa, "natural", por aqui, é inicialmente a negaçáo da natureza (o que implica, no limite, a negação do passado pré-colombiano ${ }^{15}$ ); isso com a esperança de que, em algum momento, a civilização moderna assim criada se enraíze: naturalize-se.

Finalmente, Alfredo Bosi recobra o motivo do "transplante" em trabalhos como "Formaçôes ideológicas na cultura brasileira" e Dialética da colonizaçáo. Neste, provavelmente o seu ensaio de maior repercussão, o problema se aproxima dos marcos do universalismo católico, que se oferece como baliza para os desvios e desafios que caracterizaram o processo colonizador. Nesse sentido, Bosi (1992, p. 93) comenta a cisão que haveria em Anchieta - entre seu teatro de catequese e sua lírica:

Anchieta fala não só línguas várias, mas linguagens distintas conforme o auditório. $\mathrm{O}$ universalismo cristão, peculiar à mensagem evangélica dos

14“Num oásis se impõe uma alta disciplina civilizadora. 'A vida', diz Worringer, 'concentrada num oásis estreito, toma, ao chegar ao ponto, a forma disciplinada de um cultivo de viveiro'. A característica maior dessa civilização de oásis é a extremamente natural facilidade com que recebe as formas culturais mais externas e mais altas e a naturalidade extrema com que nega a própria natureza. Nela, o 'natural' é negar a natureza. Nessa negação naturalíssima está o seu formidável poder de absorção de quaisquer contribuiçôes culturais, por mais complexas e altas que sejam, venham de onde vierem. / Eis por que, americanos, brasileiros, estamos, como já tivemos ocasião de dizer, 'condenados ao moderno'. O moderno vai sendo cada vez mais o nosso habitat natural. A América não era oásis entre desertos, era simplesmente nova: lugar onde tudo podia começar do começo. Os colonos ingleses que desembarcaram ao norte do Continente o que encontraram em matéria de cultura e civilização não lhes pareceu digno de conservaçấo. Fizeram, então, tabula rasa, e, assim, puderam transplantar, por assim dizer, intatas suas formas culturais mais adiantadas, como se se tratasse de uma transplantação para oásis. Sendo nova, sendo vasta, não havendo no seu solo senáo a virgindade do mato e do solo (caso específico nosso, os do lado de cá da banda atlântica meridional), a América se fez com essas transplantaçôes maciças vindas de fora." (PEDROSA, 1998, p. 390).

15"No Brasil, nem nos entregamos à natureza, nem a dominamos. Estabeleceu-se um modus vivendi medíocre. Nunca tivemos passado, nem rastros dele por trás de nós." (PEDROSA, 1998, p. 391). 
primeiros séculos, precisa de condiçōes históricas especiais para manter sua coerência e pureza. No processo de transplante cultural a aliança do cristianismo com estratos sociais e políticos dominantes é letal para a sua integridade.

\section{Rizoma}

Neste ponto, poderíamos colocar a questáo: náo haveria como interpretar os trópicos, a colonização, o Brasil, a não ser como "transplante"? Para além dos motivos edênicos, a América só pode ser lida sob o signo de uma natureza transplantada? Segundo Bosi, o motivo participaria de uma das definiçóes do processo colonizador: "a colonização como projeto voltado para a satisfaçáo das necessidades materiais do presente (colo: eu cultivo, eu trabalho); e a colonizaçáa como transplante de um passado prenhe de imagens, símbolos e ritos de caráter religioso (cultus: a memória dos antepassados)". O projeto totalizante que envolve colonização, cultura e culto parece celebrar uma religaçáo identitária da gênese, tributária da herança teológica presentificada pela máquina biopolítica, já então globalizada, na qual se enraizariam, afinal, as arborescentes democracias contemporâneas. "Sem cultus", afirma Bosi, "colo tende a amesquinhar-se e virar pedestre utilitarismo. Colonizar é também reviver os signos de uma arcana identidade figurada pelo culto" (BOSI, 1992, p. 172).

Ora, Vicente Huidobro já afirmava a enorme diferença entre cantar a rosa e fazê-la florescer em poemas: maquiná-la. Em Mário de Andrade, no final da década de 1920, se a amazônica vitória-régia tem orientação baixa, ela parece ao turista aprendiz, não obstante, superior, cifra de um espetáculo intelectual que se oferece; em Drummond, em meados dos anos 1940, se a rosa é do povo, é a orquídea, todavia, que ganha o contorno do indecidível, da aporia $^{16}$. Di Cavalcanti, por sua vez, tracejara, em 1922, uma árvore algo minguada, desnutrida; sinal, diríamos, das lutas que deveria empreender a arte moderna contra o provincianismo da tradição. Já em Guilherme de Almeida, "príncipe dos poetas", em 1952, a orquídea é a "flor heráldica", assim como a flor-de-lis é para a França; ela germina confortável num aparelho do Estado, o Orquidário do Jardim Botânico de Sáo Paulo, onde vai, como afirma o poeta, "alçando-se em lisonjeira linha ascendente", como "um requinte de gosto, uma instintiva e intuitiva definição de Civilização" (ALMEIDA, 1952, contracapa).

${ }^{16}$ Referência aos textos: "Áporo" (1945), de Carlos Drummond de Andrade, e "Vitória-régia" (1927-1928), de Mário de Andrade (ANDRADE, 2000; ANDRADE, 2015). 
Estas são algumas das distintas máquinas em que natureza e cultura foram colocadas em tensão. Que a tradição modernista tenha produzido, em grande medida, interpretaçóes normativas, tautológicas e unificadoras para essas máquinas, lendo-as como representações de um processo, ainda que turbulento ou enfrentado, ao final necessariamente conciliatório e ascendente, em que as formas da natureza emprestariam ao povo, ao país ou à cultura uma organicidade que tenderia sempre para o alto, isso, enfim, não impede que reabramos o problema ${ }^{17}$. $\mathrm{E}$ sobretudo não impede que tentemos desativar a lógica predicativa desse idealismo arborescente. Como escreveu Raúl Antelo, "a orquídea não se forma, a orquídea é. Capta-se, é dita pela linguagem, recebe significaçáo a partir da cultura." (ANTELO, 2003 , p. 44$)^{18}$. Em outras palavras, ainda: "A literatura nacional, tantas vezes comparada a uma árvore [...] surge assim como uma investigação tautológica acerca do vazio." (ANTELO, 2019, p. 3).

$\mathrm{O}$ que Haroldo de Campos intitulou como $\mathbf{O}$ sequestro do barroco na formaçáo da literatura brasileira, ou a incompreensão do tropicalismo por parte de críticos como Roberto Schwarz e Ferreira Gullar, situam-se nos marcos desse debate a respeito da naturalização da cultura. $\mathrm{O}$ barroco de Gregório de Matos - abundante, excessivo, artificioso - contrariaria o

17 “Assim como Mário vê, na vitória-régia, a flor nacional por antonomásia, Guilherme de Almeida escolhe a orquídea como flor universal, 'um requinte de gosto, uma instintiva e intuitiva definição de Civilização'. O paradoxo reside em que tamanha definição de cultura dava-se no que há de mais real e rebaixado na cultura de massas. O texto em questão é uma matéria que Guilherme publica em um 'florilégio', uma antologia, a Seleçóes do Reader's Digest, quando a rosa do povo já estava, há tempos, se formando. Enquanto a orquídea do áporo ainda requer a disciplina de uma formação (palavra chave na conceituação hegeliana de cultura do modernismo brasileiro), a orquídea das folclóricas seleçôes populares se impóe com o peso das instituiçóes oficiais. É o próprio texto que nos informa que seu autor, o sujeito, é um acadêmico soberano e que seu objeto, a orquídea, é fruto de um Orquidário do Estado, legitimado pela Secretaria de Cultura e pela Prefeitura Municipal./ As forças desatadas pela flor reconhecem assim três orientaçóes, uma delas, baixa, a da vitória-régia em Mário, que ele reputa superior por ser um ur-fenômeno intelectual, a despeito do julgamento poético negativo dos colegas; outra, sublime, a orquídea de Guilherme de Almeida, mesmo que publicada pelo veículo mais rebaixado possível; e uma terceira, o áporo de Drummond, situada no meio do caminho entre o sublime e o abjeto. Digamos, apenas para esclarecimento do entre-lugar, que embora Drummond nunca tenha querido entrar para a Academia, não recusou escrever sobre a Minas natal para as Seleçóes, o que reitera sua característica ambivalência em muitas de suas atitudes./ Numa perspectiva mais benevolente, poderíamos pensar que o áporo de Drummond viria, fundamentalmente, sistematizar aquilo que busca a intervenção de Mário: desligar a flor de sua função e mostrar que, se afirmamos que as flores são belas, não é por aquilo que elas são de fato mas porque elas parecem adequadas ao ideal.” (ANTELO, 2003, p. 42).

18 "O verme-orquídea, segundo Bataille, seria portanto o mais acabado exemplo do informe, aquilo que desloca uma hierarquia dada." (ANTELO, 2003, p. 44). 
"pressuposto evolutivo-biológico daquela historiografia tradicional que vê reproduzir-se na literatura um processo de floração gradativa, de crescimento orgânico." (CAMPOS, 2011, p. 24). E talvez pudéssemos dizer, igualmente, que, para Schwarz e Gullar, o tropicalismo era excessivamente "tropical", isto é, era por demais maquínico, rizomático, promovendo agenciamentos que fugiam à unidade e à pretensão teleológica de continuidade e de desenvolvimento. E nesse sentido também poderia ser pensada a leitura de Araripe Júnior, que privilegia a obnubilaçâa dos trópicos como uma força arcaica capaz de inflamar a imaginação em detrimento das formas civilizacionais, imperativas, da razão. Uma força que se manifesta não como determinismo, portanto, mas como contingência que produz, que agencia uma descontinuidade, um vazio, uma "fenda". Trata-se, em suma, da exposiçâo reiterada da cultura como técnica; são "camadas de hábitos":

A esse fenômeno, durante o qual, como se vê, adelgaçaram-se, atenuaram-se todas as camadas de hábitos que subordinavam o homem à civilizaçáo, abriuse uma fenda na estratificação da natureza civilizada, para dar passagem à poderosa influência do ambiente primitivo; a esse fenômeno, que se acentua a cada passo no movimento da vida colonial ou aventureira do século XVI, poder-se-ia dar o nome de obnubilaçâo brasílica, e, sem dúvida, sobre ele basear-se toda a teoria histórica daquela época indecisa. (JÚNIOR, 1958, p. 497).

Nesse sentido, o tropicalismo - e, antes dele, a antropofagia de Oswald de Andrade, como pode ser lida em Pau Brasil-sendo muito pouco opositivo ou hierárquico, muito pouco filial, teria como princípio a obnubilação. Se nos lembrarmos dos Bólides, dos Parangolés, da Tropicália e, principalmente, da proposição nomeada por Hélio Oiticica como Subterrânia (figura 2), no final da década de 1960, sem dúvida teremos elementos significativos para compreender a sua força disruptiva ${ }^{19}$. Sua formulaçáo, simultaneamente estética, ética, política e tática, é notadamente rizomática, nômade ou desterritorializante, desdobrando-se numa série de textos, projetos, açôes, interlocuçóes etc. ${ }^{20}$ Com Subterrânia, Oiticica postula uma força elementar,

\footnotetext{
19"Pouco depois de Apocalipopótese, Oiticica viaja para Londres e de lá volta para o Brasil em 1970. Entre os meses de setembro e outubro de 1969, dedica-se às elaboraçóes do conceito Subterrânia e escreve dois textos em forma de manifesto: Subterrânia e Subterrânia 2. [...] Subterrânia é publicada no Pasquim em 1970 na seção Underground editada por Luiz Carlos Maciel." (CERA, 2012, p. 57-58).

20"Como esforço político de criação, subterrânia pode ser entendida como a construção rizomática de outros mundos através de agenciamentos coletivos - seus ninhos - os motores criadores de multiplicidades. [...] a consciência subterrânia construtiva de mundos é, à maneira
} 
diríamos que efetivamente imprópria; quer dizer, seu princípio operatório não se basearia na exclusão ("ou"), mas na conjunção ("e"): "SOU EU É VOCÊ É AMÉRICA LATINA SUL SUB embaixo da terra [...] subterra: romântico cafono clássico ortodoxo folk-pop consciente místico lírico (+neo +sub tudo) [...]" (OITICICA apud CERA, 2012, p. 60).

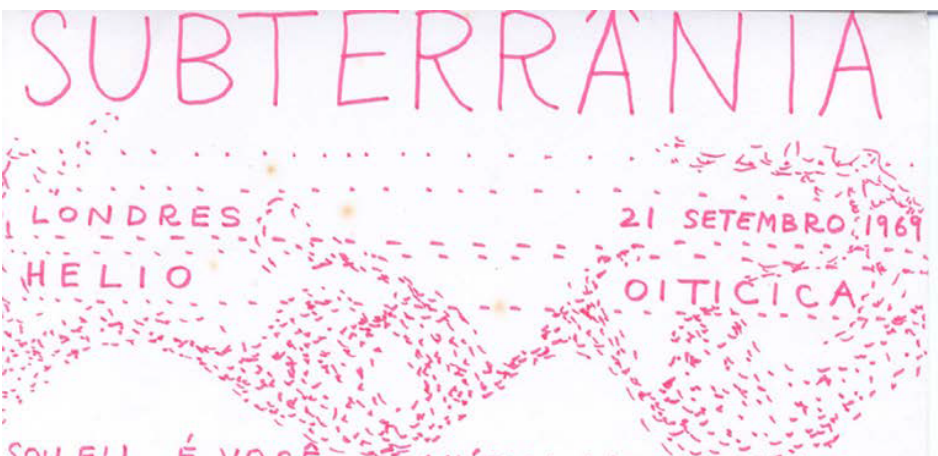

SOU EU É VOCÊ E AMÉRICA LATINA E E SUL SUB embaixo da terra longe do falatório dentro de vocé no Brasil $\longrightarrow$ no submundo algo nasce genmina culmina ou é fulminado como fênix nasce da própria cinza (cofono) $\rightarrow$ subterra: romántico cafono clássico onto doxo folk-pop consciente místico línico (tneo + sub tudo) tropicália é o grito do Brasil para o mundo $\longrightarrow$ subterrâna do mundo para o Brasil : nā̄ queno usan "undergnound" (édificil demais pro brasileino) mas subtennânia é a glonificaçao do sub + atividade homem $=$ mundo $=$ manifest aces : $\frac{n \text { ar }}{\text { como detnimento }}$ ou glomi-condigar $\rightarrow$ sim: como consciéncia para vencer a super a paranbia - repressã̃ - impotencia negligência do viver: marcha fúnebre $\rightarrow$ entênno egnito consciência $=$ crítica - creativa - ativa $\longrightarrow$ necessidade $=$ do disfance $=$ do sunnealismo-farsa $=$ to sub-sub - da redundância $\longrightarrow$ longe dos olhos $\longrightarrow$ pento do conação: ou da côn da açás: debaixo da terna - omo rato de si mesmo: RATO é o que somos simbolo flama intennemo-nos vivos desapaneçamos sejamos o nā donä

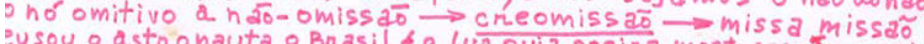
susou o astronauta o Bnasil é a Lua cuja poeina mostnarse-áa mundo sublixe

Figura 2: Hélio Oiticica, Subterrânia, 1969.

Fonte: Flávia Cera (2012, p. 60).

do rizoma, 'voltada para uma experimentação ancorada no real' [...]. A subterrânia, por não ter fixaçáo de raiz, torna-se móvel e portátil" (CERA, 2012, p. 66). 
Um agenciamento, como vimos, se dá com o dado, com a terra, com a floresta e com o rio - mas também com o livro, com a imagem, com o barco e com o aviáo. Entre uma coisa e outra estava o Amazonas de Michaux e de Euclides. Entre uma coisa e outra, o Brasil suspenso, mapeado por Finazzi-Agrò. Ao reivindicar a prótese do descobrimento, no contexto de pugna entre ficções, Luis Felipe Noé resumiu: somos $e$ não somos. Algo que Deleuze e Guattari assim formularam, na proposição da máquina de guerra que é Mil platôs:

\begin{abstract}
Um rizoma náo começa nem conclui, ele se encontra sempre no meio, entre as coisas, inter-ser, intermezzo. A árvore é filiação, mas o rizoma é aliança, unicamente aliança. A árvore impóe o verbo "ser", mas o rizoma tem como tecido a conjunção "e... e... e..." Há nesta conjunção força suficiente para sacudir e desenraizar o verbo ser. Para onde vai você? De onde você vem? Aonde quer chegar? São questôes inúteis. Fazer tabula rasa, partir ou repartir de zero, buscar um começo, ou um fundamento, implicam uma falsa concepção da viagem e do movimento (metódico, pedagógico, iniciático, simbólico...). [...] Entre as coisas não designa uma correlação localizável que vai de uma para outra e reciprocamente, mas uma direçâo perpendicular, um movimento transversal que as carrega uma $e$ outra, riacho sem início nem fim, que rói suas duas margens e adquire velocidade no meio (DELEUZE; GUATTARI, 1995, p. 36-37).
\end{abstract}

Essa palavra estratégica - entre - é a cifra da posição demandada por Silviano Santiago. Ao recusar a prática ainda corrente no início dos anos 1970 de investigação das fontes e das influências - essa "curiosa verdade", escreve o autor, que "prega o amor da genealogia" e o reconhecimento de "uma dívida contraída" (SANTIAGO, 1978, p. 19) -; ao recusar igualmente a abordagem "pseudomarxista" que emparelha a facilidade da leitura à sua suposta eficácia, Santiago reafirma que, se o combate existe e é necessário, ele deve se dar entre:

Entre o sacrifício e o jogo, entre a prisão e a transgressão, entre a submissão ao código e a agressão, entre a obediência e a rebelião, entre a assimilação e a expressáo - ali, nesse lugar aparentemente vazio, seu templo e seu lugar de clandestinidade, ali, se realiza o ritual antropófago da literatura latinoamericana. (SANTIAGO, 1978, p. 26).

O Amazonas, a natureza - a primavera passa pela palavra, espécie de riacho sem início nem fim que rói as próprias margens e ganha velocidade no meio: num lugar aparentemente vazio, como entre a letra e o leito, ou 
como entre os dentes. Apenas no centro dessa engrenagem pode haver a leitura, a invenção, ela também uma máquina, uma contra-mola, como pensaram João Ricardo e João Apolinário, por volta daqueles mesmos anos:

PRIMAVERA NOS DENTES

Quem tem consciência para ter coragem

Quem tem a força de saber que existe e no centro da própria engrenagem inventa a contra-mola que resiste

Quem não vacila mesmo derrotado Quem já perdido nunca desespera e envolto em tempestade, decepado entre os dentes segura a primavera (RICARDO; APOLINÁRIO, 1973, LADO A, faixa 5)

Para Yuyo Noé

\section{Referências}

AGAMBEN, Giorgio. Homo sacer. Tradução Henrique Burigo. Belo Horizonte: UFMG, 2007.

AGAMBEN, Giorgio. Tempo e história: crítica do instante e do contínuo. In: AGAMBEN, Giorgio. Infância e história. Tradução Henrique Burigo. Belo Horizonte: UFMG, 2008, p. 109-128.

ALMEIDA, Guilherme de. Orquídea, flor de altura. Seleçóes do Reader's Digest, Rio de Janeiro, vol. 22, n. 126, jul. 1952, contracapa.

ANDRADE, Carlos Drummond de. A rosa do povo. 21 ed. Sáo Paulo: Record, 2000.

ANDRADE, Mário de. O turista aprendiz. Brasília, DF: Iphan, 2015.

ANTELO, Raúl. A aporia da leitura. Ipotesi: Revista de Estudos Literários, Juiz de Fora, v. 7, n. 1, p. 31-45, 2003. Disponível em: http://www.ufff.br/ revistaipotesi/files/2011/05/4-A-aporia-da-leitura.pdf. Acesso em: 25 set. 
2019.

ANTELO, Raúl. Mas, onde fica a viagem? Confluenze. Rivista di Studi Iberoamericani. Bologna, vol. 4, n. 1, p. 1-14, 2012. Disponível em: https://confluenze.unibo.it/article/view/3079. Acesso em: 25 set. 2019.

ANTELO, Raúl. O Museu é um espelho ustório. Remate de Males, v. 39, n. 1, p. 4-27, jul. 2019. Disponível em: https://doi.org/10.20396/remate. v39i1.8654438. Acesso em: 25 set. 2019.

BOSI, Alfredo. Dialética da colonizaçáo. São Paulo: Companhia das Letras, 1992.

CAMPOS, Haroldo de. O sequestro do barroco na Formaçáo da Literatura Brasileira: o caso Gregório de Matos. São Paulo: Iluminuras, 2011.

CANDIDO, Antonio. Formaçáo da literatura brasileira. Momentos decisivos. 6. ed. Belo Horizonte: Itatiaia, 2000.

CAPELA, Carlos Eduardo. Nos confins de Judas. São Paulo: Lumme, 2011.

CERA, Flávia Letícia Biff. Arte-vida-corpo-mundo, segundo Hélio Oiticica. Tese de Doutorado em Literatura. Programa de Pós-Graduação em Literatura, UFSC, Florianópolis, 2012.

COMPAGNON, Antoine. Os cinco paradoxos da modernidade. Tradução Cleonice P. Mourão, Consuelo F. Santiago e Eunice D. Galéry. Belo Horizonte: UFMG, 1996.

COUTINHO, Afrânio. A literatura no Brasil. 3. ed. Rio de Janeiro: José Olympio, 1986.

CUZZANI, Agustín. Los indios estaban cabreros. Buenos Aires: Editorial Talía, 1958.

DELEUZE, Gilles; GUATTARI, Felix. Mil Platôs. Capitalismo e esquizofrenia. Vol. 1, Tradução Aurélio Guerra Neto e Celia Pinto Costa. São Paulo: Ed. 34, 1995.

FINAZZI-AGRÒ, Ettore. Entretempos: mapeando a história da cultura brasileira. 1. ed. São Paulo: Editora Unesp, 2013.

FREYRE, Gilberto. Casa-grande \& Senzala. 48. ed. São Paulo: Global, 2003.

FOUCAULT, Michel. O nascimento da biopolítica. Curso dado no Collège de France (1978-1979). Tradução Eduardo Brandão. São Paulo: Martins Fontes, 2008. 
GIORGI, Artur de Vargas. A primeira fundação de Buenos Aires, ainda. Pós: Belo Horizonte, v. 6, n. 12, p. 62-72, nov. 2016. Disponível em: https://www.eba.ufmg.br/revistapos/index.php/pos/article/view/445. Acesso em: 25 set. 2019.

GIUCCI, Guillermo. Viajantes do maravilhoso: o Novo Mundo. Tradução Josely Vianna Baptista. São Paulo: Companhia das Letras, 1992.

GREENBLATT, Stephen. Possessóes maravilhosas: o deslumbramento do Novo Mundo. Tradução Gilson César Cardoso de Souza. São Paulo: EDUSP, 1996.

GULLAR, Ferreira. Vanguarda e subdesenvolvimento. In: GULLAR, Ferreira. Cultura posta em questáo, Vanguarda e subdesenvolvimento. 2 . ed. Rio de Janeiro: José Olympio, 2006.

HOLANDA, Sérgio Buarque de. Raízes do Brasil. 26. ed. São Paulo: Companhia das Letras, 1995.

HOLANDA, Sérgio Buarque de. Visáo do paraíso: os motivos edênicos no descobrimento e colonização do Brasil. São Paulo: Companhia das Letras, 2010.

JUNIOR, Araripe. Literatura brasileira. In: COUTINHO, Afrânio (org.). Obra crítica de Araripe Junior. Volume I (1868-1887). Rio de Janeiro: Ministério da Educação e Cultura; Casa de Rui Barbosa, 1958.

LÉRY, Jean de. Viagem à terra do Brasil. Tradução Sérgio Milliet. Belo Horizonte: Itatiaia; São Paulo: Edusp, 1980.

LINK, Daniel. León Ferrari: la experiencia exterior. In: León Ferrari Brailles y relecturas de la Biblia. Curaduría: Florencia Battiti. Buenos Aires: MALBA, 2012.

MONTAIGNE, Michel de. Dos canibais. In: MONTAIGNE, Michel de. Ensaios. Volume I. Tradução Sérgio Milliet. São Paulo: Nova Cultural, 1996, p. 192-202.

NANCY, Jean-Luc. Lo excrito. In: NANCY, Jean-Luc. Un pensamiento finito. Traducción Juan Carlos Moreno Romo. Barcelona: Anthropos, 2002. NOÉ, Luis Felipe. A Oriente por Occidente. Descubrimiento del llamado descubrimiento o (del origen) de lo que somos y no somos. Bogotá: Ediciones Arte Dos Gráfico, 1992.

OSKI. Vera historia de Indias. Buenos Aires: Colihue, 2006.

PEDROSA, Mário. Reflexôes em torno da Nova Capital. In: ARANTES, Otília (org.). Acadêmicos e Modernos: textos escolhidos III. São Paulo: 
Edusp, 1998, p. 389-406.

REP, Miguel; VACCARI, Laura (Ed.). Oski: un monje enloquecido. Buenos Aires: Museo Nacional de Bellas Artes, 2013.

RIBEIRO, Darcy. As Américas e a civilizaçáo. São Paulo: Cia das Letras, 2007.

RICARDO, João; APOLINÁRIO, João. Primavera nos dentes. In: SECOS \& MOLHADOS, Secos \& Molhados. [S.I.]: Continental, 1973. 1 disco sonoro. LADO A, faixa 5.

SANTIAGO, Silviano. O entre-lugar do discurso latino-americano. In: SANTIAGO, Silviano. Uma literatura nos trópicos. São Paulo: Perspectiva, 1978, p. 11-28.

SCHMIDL, Ulrico. Crónica del viaje a las regiones del Plata, Paraguay y Brasil. Traducción Edmundo Wernicke. Buenos Aires: Ediciones de la Veleta, 1993 (Con ilustraciones; del manuscrito de Stuttgart, con anotaciones críticas, precedido de estudios; original y editio princeps de 1567).

SCHWARZ, Roberto. Nacional por subtração. In: SCHWARZ, Roberto. Que horas são? Ensaios. São Paulo: Companhia das Letras, 1987, p. 29-48. STADEN, Hans. Duas viagens ao Brasil. Tradução Guiomar de Carvalho Franco. Belo Horizonte: Itatiaia; São Paulo: Edusp, 1974. 